\title{
The Collapse of the United States Banking System during the Great Depression, 1929 to 1933, New Archival Evidence
}

\author{
Gary Richardson \\ Department of Economics, University of California
}

\begin{abstract}
During the Great Depression, one third of all banks in the United States failed. Scholars dispute reason for their demise. This essay analyzes new evidence on the sources of bank distress. The data demonstrates that contagion via correspondent networks and bank runs propagated the initial banking panics in the fall of 1930. As the depression deepened and asset values declined, insolvency loomed as the principal threat to depository institutions. These patterns corroborate some and question other conjectures concerning the causes and consequences of the financial crisis during the Great Contraction.
\end{abstract}

Key Words: Great Depression; Federal Reserve; banking panics; financial crisis; contagion; suspension.

\section{INTRODUCTION}

The causes, consequences, and possibilities of preventing the banking panics of the Great Depression have been debated for seven decades. The debate's factual foundations rest upon data published in the Federal Reserve Bulletin. The September 1937 issue contains the only comprehensive collection of statistics on suspended banks, and is the sole source of aggregate bank failure rates (Board of Governors 1937, hereafter FRB'37). Scholars studying the contraction continuously redefine, reinterpret, and reveal new correlations between data from FRB'37 and measures of industrial, commercial, and financial activity.

The principal reason the debate continues may be the single source of evidence. FRB'37 provides imperfect information about bank distress. It distinguishes neither temporary from terminal suspensions, nor voluntary from involuntary liquidations, nor institutions afflicted by illiquidity from banks suffering insolvency. It contains information neither on the causes of bank suspensions nor the number of bank mergers. The smallest period of aggregation at the national level is the month and at the Federal Reserve district level is the year. Key terms remain undefined, leaving much open to interpretation.

This article introduces new statistical series that provides precise, detailed, aggregate information about categories of bank distress and causes of bank suspensions. The source for the new series is the same as for the old series. From 1929 though 1933, the Board of Governors collected data on changes of status for all banks operating in the United States, both members of the Federal Reserve System and nonmembers, state and national, incorporated and private. The Board also analyzed the cause of each bank suspension. The Division of Bank Operations recorded this information on the St. 6386 series of forms. The series comprehensively covered the commercial banking industry from January 1929 through the national banking holiday in March 1933. Observations existed for every event affecting every bank. These events included the major, such as openings, closings, reopenings, receiverships, and consolidations, and the minor, such as changes in Federal Reserve membership, capital stock, charter type, and even street address. The forms also 
included financial information for each bank on the date of each transaction. The complete series of St. 6386 forms survives in the National Archives of the United States.

Since the St. 6386 database covers the entire population of banks and events, analysis of it may be conducted in a manner more straightforward than in the current literature, where scholars employ the FRB'37 series, samples of microdata from various sources, economic logic, and statistical techniques to infer patterns of events, and where conclusions depend upon, beliefs arise from, and debate revolves around the assumptions underlying the analysis. Now, there is no need to argue over the nature and timing of events. The St. 6386 database reveals what in fact occurred to every bank in the nation on every day of the contraction.

This article analyzes aggregate series derived from the database using non-parametric methods. The goal is filter the data as little as possible, allowing the evidence - and the hundreds of bank examiners, accountants, receivers, economists, Federal Reserve agents, and others who collaboratively created this data set - to speak for itself. Summary statistics, charts, and graphs demonstrate that some types of bank distress were less prevalent than the conventional wisdom claims; other types of bank distress, such as temporary banks suspensions, contagion through correspondent networks, and suspensions due to illiquid assets, which according to the conventional wisdom seldom (or never) occurred, did in fact occur and played a pivotal role in the collapse of the banking system.

This direct examination of the definitive data for the entire population of banks and events answers two fundamental questions about the contraction: when did banks fail? Why did banks fail? An accurate answer to the latter must be extended, because the nature of the banking crisis changed over time. Before October 1930, the pattern of failures resembled the pattern that prevailed during the 1920s. Small, rural banks with large loan losses failed at a steady rate. In November 1930, the collapse of correspondent networks triggered banking panics. Runs rose in number and severity after prominent financial conglomerates in New York and Los Angeles closed amid scandals covered prominently in the national press. More than a third of the banks which closed their doors to depositors soon resumed normal operations. Following Britain's departure from the gold standard in September 1931, the depression deepened. Asset values declined. Insolvency loomed as the largest threat facing depository institutions. During the financial crisis in the winter of 1933, almost all of the banks that failed were liquidated at a substantial loss.

Overall, between the Great Crash and the Banking Holiday in March 1933, both illiquidity and insolvency were substantial sources of bank distress. Nearly three fourths of the banks that closed their doors due to financial difficulties were insolvent. Slightly more than one quarter were solvent, and without outside financial assistance, reopened for business, or repaid all of their depositors and creditors, or merged at face value with other institutions. Frozen and devalued assets were a primary cause of approximately one half and a contributing cause of another one quarter of all bank suspensions. Heavy withdrawals were a primary cause of slightly under one half and a contributing cause of another one sixth of all bank suspensions.

The rest of this article substantiates this depiction of the banking crises of the Great Contraction. Section 1 reviews the relevant literature, highlights FRB'37's role in academic debates, and elucidates the utility of the new evidence. Section 2 describes the data, defines key concepts, and compares the archival evidence to the old FRB'37 series. Section 3 presents chronological patterns for the four categories of bank distress: terminal suspensions, temporary suspensions, consolidations due to financial difficulties, and voluntary liquidations. Section 4 presents chronological patterns for the principal causes of bank suspensions: heavy withdrawals, problematic assets, the closure of correspondent banks, defalcations, and mismanagement. Section 5 
discusses the implications these chronological patterns, which corroborate some conjectures, cast doubt on others, and raise new questions concerning the causes and consequences of the collapse of the banking system during the Great Depression.

\section{REVIEW OF THE LITERATURE}

Scholars ask three big questions about the banking system during the Great Depression. Why did bank suspensions surge at certain points in time? How bank suspensions affect commercial and industrial activity? Could Federal Reserve intervention have prevented (or did its actions trigger) this crisis? Despite 70 years of analysis, debate persists about the answer to each inquiry.

Concerning causes of the banking crises, some scholars conclude that banks failed because the economy contracted. Loan default rates rose. Asset values declined. Deteriorating fundamentals forced banks into insolvency, continuing a process of liquidation that began during the 1920s. ${ }^{1}$ Other scholars conclude that a contagion of fear, a flight to cash holdings, and withdrawals en masse drained deposits from banks and pushed financial markets towards collapse. Illiquidity of assets and Federal Reserve inaction exacerbated the credit crunch. ${ }^{2}$

Concerning the consequences of the banking crises, some scholars see bank failures as symptoms of ongoing events with no special role in the propagation of the downturn. Other scholars believe that banking panics had monetary effect. Panics eroded depositors' confidence, induced further withdrawals, forced banks to liquidate assets at deep discounts, lowered asset prices, encourage banks to hold excess reserves, and reduced the money multiplier. This vicious cycle reduced the money supply and turned what would have been a typical recession into a cataclysmic contraction. ${ }^{3}$ Another set of scholars maintains that bank panics influenced economic activity by disrupting financial intermediation. Bank failures increased the cost of credit intermediation, dislocated the financing of small and medium firms, disrupted current production, and curtailed investment spending. This financial acceleration lowered the economy deeper into depression. ${ }^{4}$

Concerning the possibilities of preventing the banking panics, some scholars argue the Federal Reserve could have done little to aid ailing banks. Fundamental forces pushed banks into insolvency; monetary intervention could not pull them out. Liquidity assistance could not eliminate loan losses. Open-market expansion - even on a massive scale - could not lift the economy out of the liquidity trap (Temin 1976). Other scholars argue that the Federal Reserve could not aid ailing banks directly, since illiquidity and contagion caused few banks failures, but that massive openmarket expansions, such as those that the Roosevelt administration implemented after abandoning the gold standard, could reignite economic progress, and thus, indirectly alleviate the banking situation (Calomiris and Mason 2003, Eichengreen 1992, Romer 1992, Temin 1989). Another set of

1 Peter Temin (1976) argues that real, rather than monetary, forces caused banks to fail and the economy to contract by regressing state-level FRB'37 suspension data on various explanatory variables. Charles Calomiris and Joseph Mason (2003) support the supposition that contagion forced banks to fail by regressing time-to-liquidation for individual Fed member banks on an array of bank characteristics, aggregate variables, and state-level FRB'37 suspension rates. Eugene N. White (1984) initiated the use of bank balance sheet data to analyze these issues.

2 Milton Friedman and Anna Schwartz (1963) argue that the Federal Reserves' failure to act as a lender of last resort, prevent banking panics, and stem the decline of the money supply transmogrified what would have been an ordinary recession into the Great Depression by examining seasonally-adjusted series of deposits in suspended banks from FRB'37 to determine the dates of banking panics and correlating those dates with changes in monetary aggregates. Elmus Wicker (1996) uses district-level data on suspensions from FRB'37 to illuminate the regional patterns of panics.

3 Friedman and Schwartz (1963) contains the seminal statement of the monetarist position.

4 Ben Bernanke (1982) regresses growth rates of industrial production on first differences of deposits in suspended banks to show that suspensions increased the cost of credit intermediation 
scholars argue that even limited assistance from the Federal Reserve might have mitigated banking panics. By acting as a lender of last resort and extending loans to solvent but illiquid institutions, the Federal Reserve could have kept ailing institutions afloat. A credible commitment to do so might have calmed consumers, reassured bankers, raised the money multiplier, alleviated the credit crunch, and eased the economic situation (Richardson and Troost 2005). A final and influential set of scholars concludes that the Federal Reserve's sins were of commission as well as omission. The Federal Reserve not only neglected to aid ailing banks, but by raising interest rates, reducing the monetary base, and restricting discount lending, the Federal Reserve weakened all banks, and created conditions conducive to panics. As evidence, these scholars highlight the Federal Reserve's monetary contraction in 1928 and the Federal Reserve's defense of the gold standard in 1931 (Friedman and Schwartz 1963, Meltzer 2003).

Much of the academic debate focuses on competing interpretations of the Depression's initial banking crisis in the fall of 1930. According to Friedman and Schwartz (1963), the crisis began when "a contagion of fear spread among depositors (Friedman and Schwartz 1963, p. 308)." The contagion began in agricultural areas and accelerated after the failure of the Bank of the United States, which was the largest commercial bank ever to have failed up to that time in U.S. history, and whose distinctive name "led many at home and abroad to regard it somehow as an official bank (Friedman and Schwartz 1963, pp. 309-11).” The panic spread more rapidly than it would have under the pre-Federal Reserve banking system, because the existence of the Federal Reserve prevented banks from restricting the conversion of deposits into currency, which would have cut the "vicious circle set in train by the search for liquidity." Such a restriction would almost certainly have prevented the subsequent waves of bank failures that were destined to come in 1931, 1932, and 1933, just as restriction in 1893 and 1907 had quickly ended bank suspension arising primarily from lack of liquidity (Friedman and Schwartz 1963, p. 311).”

According to Wicker $(1980,1996)$, the collapse of Caldwell and Company triggered the crisis. Caldwell controlled one of the largest banking chains in the South, with assets over $\$ 200,000,000$, and one of the largest insurance groups in the region, with assets over \$230,000.000. Questionable managerial and financial practices caused the firm's demise, which quickly forced the suspension of the Bank of Tennessee and its affiliates.

According to Temin and White, the first banking crisis was caused by worsening fundamental factors, rather than contagion among banks. Temin (1976) argues that the Stock Market Crash, the Dust Bowl, and the ensuing financial, agricultural, and industrial depressions reduced the value of bank's investments and raised suspension rates. White argues that the bank failures during 1930 "did not mark a departure from previous experience (White 1984, p. 135).” Both real and monetary factors played a part. Poorly performing assets and restrictive monetary policy were both contributing factors. The former pushed banks towards insolvency. The latter raised banks' costs by forcing them to seek costly sources of funds such as bills payable, acceptances, and rediscounts. Since banks failed for those reasons throughout the 1920s and since national "bank failures can be predicted a year in advance with some accuracy (White 1984, p. 135)," the banking failures during the fall of 1930 appear to be an accentuation of prior trends, rather than a turning point in the propagation of the Great Depression. ${ }^{5}$

\footnotetext{
White (1984) pioneered efforts to examine samples of data from national banks. Subsequent work examines banks within individual cities, states, and Federal Reserve districts (Charles Calomris and Joseph Mason 1997, Mark Carlson 2004). The most recent and comprehensive work (Calomiris and Mason 2003), which analyzes a panel of all Federal Reserve member banks, yields a strong and stark conclusion. The "two Friedman-Schwartz crises are not associated with positive unexplained residual failure risk, or increased importance of bank illiquidity for forecasting failure (2003).”
} 
The data introduced by this article demonstrates that all of these views have merit. Each portrays a portion of a complex, dynamic mosaic. Conclusions which rely solely upon FRB'37 differ because the data are open to interpretation. Conclusions based upon panels of microdata differ because the samples depict certain types of events (such as liquidations) affecting certain banks (such as national banks) in particular times and places. Reconciling these views requires comprehensive, definitive data. The remainder of this article turns to that task.

\section{DATA DEFINITIONS, QUALITY, AND COMPARISONS}

During the 1920s, the Federal Reserve Board of Governors developed a lexicon for discussing bank distress and procedures for collecting data on the phenomenon. A series of memorandum delves into details of the definitions and the collection process (Board of Governors 1929, 1930, and 1931). This section concisely characterizes the key concepts before comparing the archival evidence to previously published tabulations. A series of companion papers provides additional details (Richardson 2006a, 2006b, 2006c, and 2006d). The comparison demonstrates two important points. First, the archives retain the original data set in its entirety. Second, the archival evidence contains information previously unavailable to scholars.

In the Federal Reserve's lexicon, a suspension was a bank that closed its doors to depositors and ceased conducting normal banking business for at least one business day. Some, but not all, suspended banks reopened for business. A liquidation was a permanent suspension. A liquidating bank closed its doors to the public, surrendered its charter, and repaid depositors, usually under the auspices of a court appointed officer known as a receiver. A voluntary liquidation was a category of closure in which banks ceased operations and rapidly arranged to repay depositors the full value of their deposits. Voluntary liquidations did not require the services of receivers and were not classified as suspensions. A consolidation (or merger) was the corporate union of two or more banks into one bank which continued operations as a single business entity and under a single charter. The categories of bank distress were typically construed to be temporary suspensions, terminal suspensions (i.e. liquidations), voluntary liquidations, and consolidations due to financial difficulties.

The Federal Reserve attributed most bank suspensions to one of five common causes. The first was slow, doubtful, or worthless paper. The term worthless paper indicated an asset with little or no value. The term doubtful paper meant an asset unlikely to yield book value. The term slow paper meant an asset likely to yield full value in time, but whose repayment lagged or which could not be converted to full cash value at short notice. The second common cause of suspension was heavy withdrawals, the typical example being a bank run. The third was failure a banking correspondent. Correspondents were banks with ongoing relationships facilitated by deposits of funds. A typical example is a county bank (the client) which kept its reserve deposits within and cleared its checks through a national bank in a reserve city (the correspondent). The fourth common cause was mismanagement. The fifth was defalcation, a monetary deficiency in the accounts of a bank due to fraud or breach of trust. 


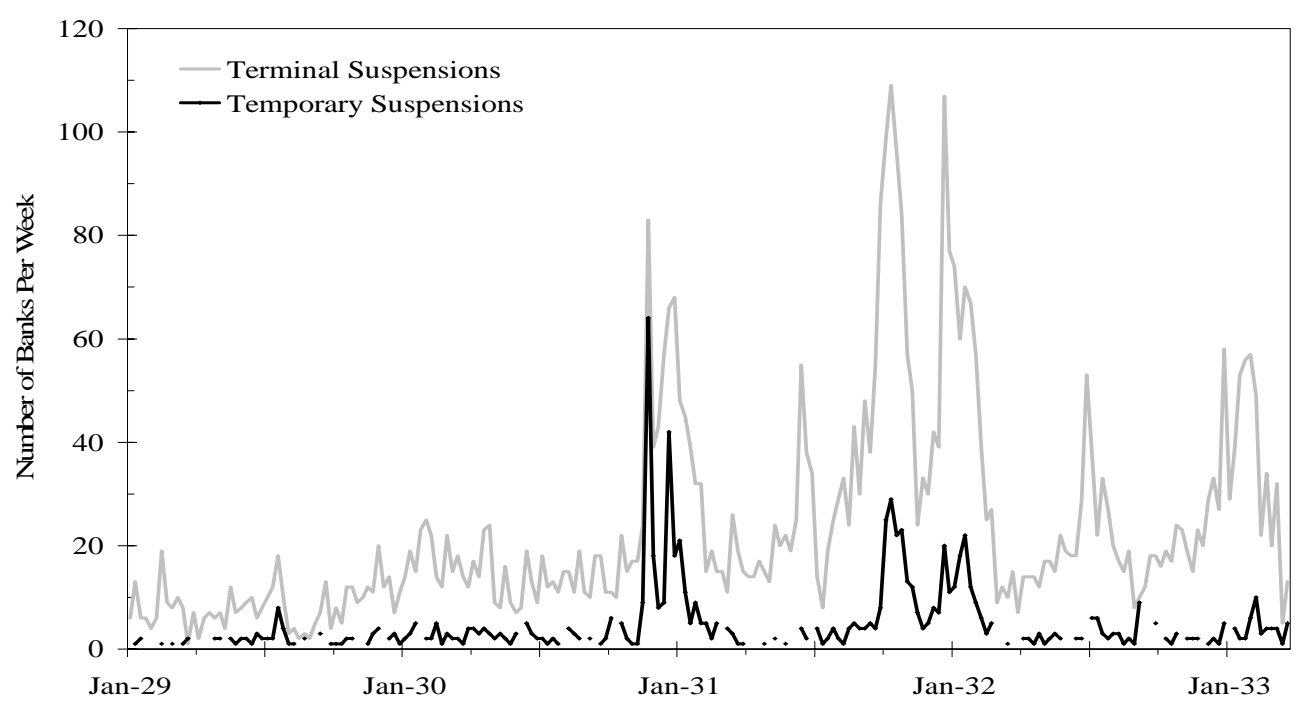

Source: National Archives and Record Administration.

\section{CATEGORIES OF BANK DISTRESS}

Figure 1 displays patterns of terminal and temporary suspensions from January 1929 to March 1933. The rates of both types of suspensions remained near pre-depression levels until November 1930, when the rates rose to levels unseen since the turn of the century. The rise in temporary suspensions was particularly pronounced. Few temporary suspensions occurred during typical weeks; many weeks witnessed none. Almost all temporary suspensions occurred during waves of bank failures such as the banking crisis of fall 1930, when more than $40 \%$ of all institutions which closed their doors to depositors soon reopened for business. The percentage fell as the depression progressed. Less than $20 \%$ of the banks which closed their doors during the fall of 1931 later reopened. Only a small fraction of the banks which suspended operations during 1932 and 1933 reopened, and most of those that did manage to resume operations did so after receiving infusions of cash from stockholders, depositors, and other sources.

Figure 2 indicates rate at which banks departed from the banking business each year. The horizontal axis divides the rates into solvencies and insolvencies. The share of solvent departures appears above the axis. The numerator of this ratio consists of banks in each year which (i) voluntarily liquidated and (ii) consolidated due to financial difficulties (dark grey area) plus (iii) the number of bank mergers of banks not in financial distress (light grey). The number of mergers is a lower-bound approximation based on the number of 'net changes for other reasons' indicated in Table 3. The denominator is the number of banks in operation at the beginning of each year. The share of insolvent departures appears below the axis. The numerator is the number of terminal suspensions. The denominator is the number of banks in operation at the beginning of each year. The values for 1933 include banks which ceased operations in January, February, and March with the exception of those closed due to banking holidays declared by state and federal governments. The dotted outlines indicate the annualized rate of departure during the first three months of 1933, or in other words, what would have happened had departure rate during the first quarter continued throughout the year. The last column indicates the rates of departure averaged over the entire contraction. 
Figure 2

Solvency and Insolvency among Banks Departing the Banking Business Each Year January 1929 through March 1933

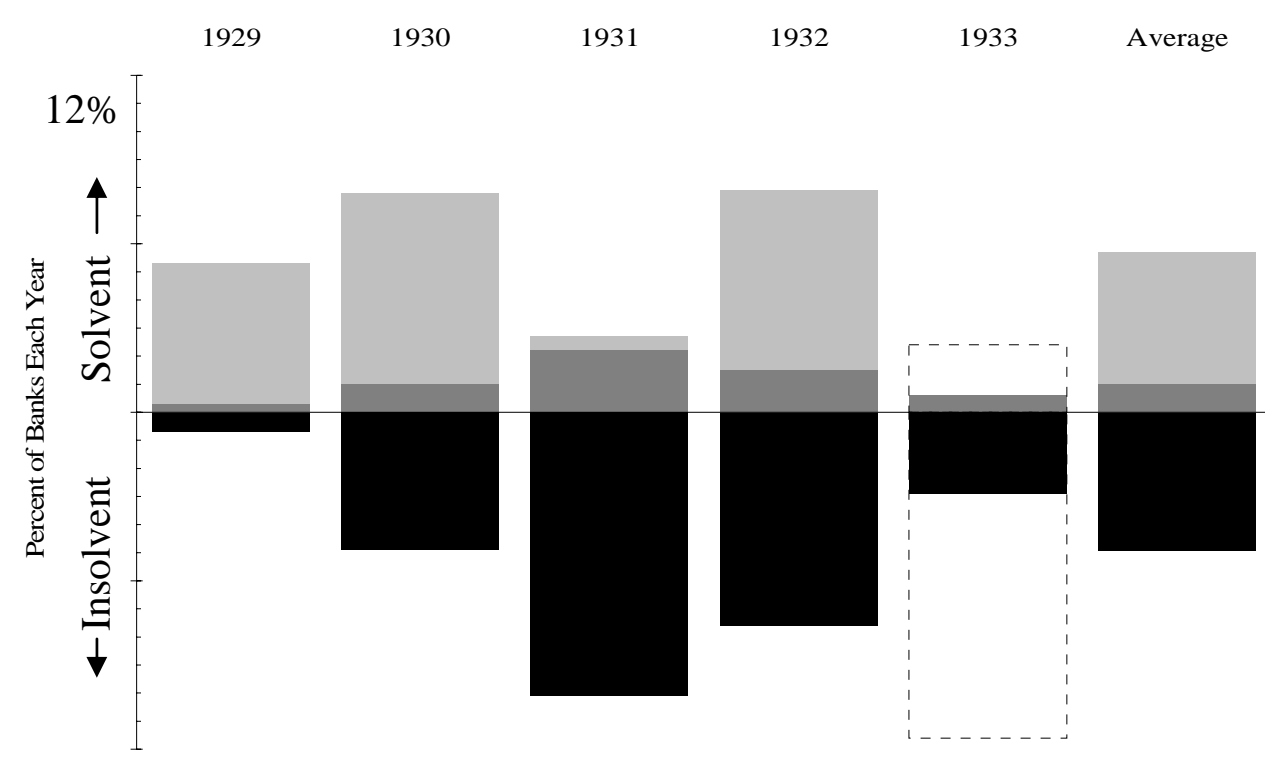

12\% Notes: Figures for 1933 include only changes occurring in January through March except those which occurred to institutions closed by government proclamation.

Source: National Archives and Records Administration and FRB’37.

Figure 2 shows that for the period January 1929 through March 1933, departures from the banking business were split about evenly between solvent and insolvent. Solvent departures principally mergers but also voluntary liquidations and consolidations under duress - were concentrated during the first two years and during the first half of 1932, a period during which the Federal Reserve System pursued an expansionary policy. Insolvent departures gradually increased during 1930 and peaked in 1931 following Britain's departure from the gold standard, to which the Federal Reserve reacted by raising the discount rate and contracting the money supply. Insolvent departures continued at a high rate in 1932 and spiked upwards during the months before the Roosevelt administration declared a national banking holiday in March 1933.

\section{CAUSES OF BANK SUSPENSIONS}

Figure 3 illuminates the issue from another perspective. It examines the shares of suspensions due to due to correspondents, withdrawals, and assets. The left-hand pie chart presents data for banks which suspended operations temporarily. The right-hand pie chart presents data for banks which suspended operations permanently. The shades of gray indicate the percentage of banks suspending for different reasons. The color black denotes banks which suspended solely due to heavy withdrawals (in key, WITHDRAWALS) but which were in fine financial shape before depositors' demanded repayment of deposits. Most of these banks experienced sudden and severe runs. Three-quarters gray denotes banks forced out of operations by heavy withdrawals and also afflicted by asset troubles that exacerbated their condition, but which were not severe enough to have necessitated suspension in the absence of withdrawals (WITHDRAWAL + assets). One-half gray indicates banks in double trouble. Problems severe enough to necessitate suspension existed on both sides of the balance sheet (WITHDRAWALS \& ASSETS). One-quarter gray indicates banks whose slow, doubtful, and worthless assets forced them to close their doors and where withdrawals 
exacerbated the situation. Examples include (i) banks forced by continuous, slow withdrawals to sell their profitable assets leaving them with a problematic portfolio, and (ii) banks headed towards failure whose demise was accelerated by depositors' demands (ASSETS + withdrawals). Lightlydotted gray indicates banks forced to suspend solely due to problematic assets (ASSETS). See the appendix for an extended discussion of these definitions and the methods which the Board of Governors employed to determine the causes of each bank's demise.

Figure 3 demonstrates that for the contraction as a whole, heavy withdrawals were the primary cause of more than a half of all temporary suspensions. The closure of counterparties caused another sixth of all temporary suspensions. Asset problems were the primary cause of less than a third of the temporary suspensions. For terminal suspensions, the pattern differed. Asset problems were the primary cause of more than half of all bank suspensions and a contributing cause of another one-quarter. More than eight in ten of the banks which went out of business, in other words, were judged to have problematic assets.
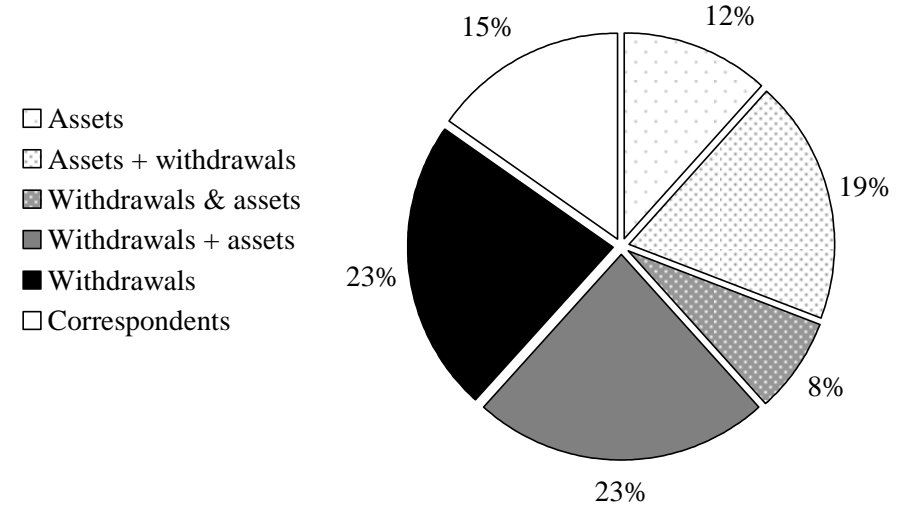

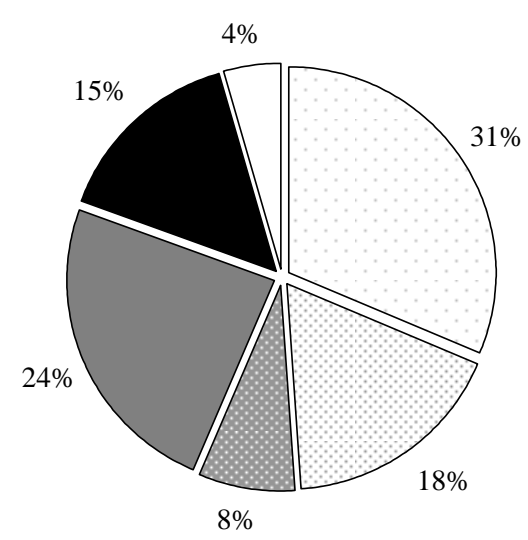

$8 \%$

Note: The pie charts above display the proportion of suspensions occurring between January 1929 and March 1933 attributed to the 6 causes listed above. Suspensions attributed to defalcation, mismanagement, multiple, and other causes were excluded from the calculations. The proportions of suspensions attributed to those causes were roughly equal.

Source: National Archives and Records Administration.

\section{DISCUSSION}

The evidence presented in the previous section corroborates the conjectures of many scholars. As Temin (1976) and White (1984) maintain, a trend of consolidation in the commercial banking industry, as small banks in rural areas left the business, often liquidating involuntarily and after suffering large losses, existed prior to the depression, continued during the contraction, and intensified as the downturn deepened.

As Wicker $(1980,1996)$ argues, the collapse of the Caldwell conglomerate triggered the initial banking panic in the fall of 1930. Correspondent networks propagated the panic during the initial weeks, when almost all of the banks which suspended operations were financially or geographically connected to the Caldwell conglomerate. Bank runs radiated outward from these focal events. Heavy withdrawals became the principal form of bank distress and forced hundreds of banks to suspend operations. Yet, as Friedman and Schwartz (1963) argue, the failure of the Bank of the United States accentuated depositors' fears and reinvigorated the panic. All three scholars, 
Friedman, Schwartz, and Wicker, argue that the crisis was a departure from previous trends, a unique event that may have altered the course of the contraction. So, the archival evidence supports a synthesis of their views while revealing additional aspects of the event. Several smaller correspondent chains, with no connection to Caldwell, imploded in Caldwell's wake. The failure of the Guaranty Building and Loan Association added fuel to the fire. Nearly half of the institutions that suspended operations as a consequence of these events rapidly reopened for business.

As Friedman and Schwartz (1963) contend, illiquidity played a role in the surge in bank suspensions in June of 1931. In that month, runs occurred on banks in Illinois. Examiners reported that heavy withdrawals were the primary cause of almost all of these suspensions. Frozen assets and limited cash reserves contributed to many closures, but none of the banks possessed portfolios which had deteriorated near the point of insolvency.

As Calomiris and Mason (1997) maintain, the Chicago banking panic of June 1932 was due to depositors' confusion about bank asset quality. Examiners reported that for the preponderance of the banks which entered receivership, the primary cause of suspensions was problems with doubtful and worthless assets. The banking panic did not produce significant numbers of failures among solvent banks.

For the remainder of the contraction, the causes of bank suspensions fit the descriptions of events offered by Temin (1976) and Calomiris and Mason (1997, 2003). Declining asset values were the principal cause of bank suspensions. Most banks which closed their doors did so permanently. All were insolvent. The few which reopened did so only after receiving outside financial assistance.

The archival evidence concurs completely with no single scholar. It shows that scholars accurately interpreted their own data, but because the nature of the financial crisis varied across time, place, and institutions, no single sample could capture the complexity and dynamism of events. An analogy is to a group of mathematicians trying to describe the slope of a curve. Each estimates a derivative at a particular point. The estimates differ, and they argue about which estimate is more accurate. The archival evidence reveals the shape of the object - say, for the sake of the analogy, $y=x^{3} \cdot \operatorname{cosine}(x)$ - curves wildly in some general direction. All of the estimates lie about the curve. So, everyone is accurate in some region, but you need to see the big picture to understand how their estimates link together.

Why did the nature of the banking crisis change over time? The archival evidence reveals the initial impetus. A series of events revealed the fragility of the banking system which had evolved since the foundation of the Federal Reserve. During the 1920s, financial markets changed rapidly. Entrepreneurs invented new financial instruments and forms of consumer credit. Individuals began investing in the equity markets to a hitherto unimagined extent. Markets became more tightly integrated across space and time. Financial conglomerates grew to take advantage of these opportunities. These new organizations included banking chains and groups and also organizations that spanned commercial and investment banking, insurance, real estate, equity trading, and brokerage services. These organizations enabled corporations and individuals to access the rapidly modernizing financial system.

In November and December 1930, these new and supposedly superior institutions showed signs of weakness. Correspondent networks (such as Caldwell's) collapsed. Banking chains (such as A.B. Banks) failed. Banking groups (such as BancoKentucky) also failed. Three prominent conglomerates - Caldwell in middle America, the Bank of the United States in New York, and the 
Guaranty Building and Loan Association in California - failed. Their demise resulted in three of the largest bankruptcies in United States to that date. Scandals swirled around each bankruptcy. Defalcation undermined each institution. False financial reports deceived investors and depositors, who lost large sums as a result. For months, newspapers throughout the nation reported the scandals at length and in depth on their front pages. The news must have altered depositors' beliefs about the safety, stability, and efficacy of the system. The public reacted by withdrawing funds, increasing holdings of currency, and switching savings to safer, older, and more transparent institutions.

This argument explains the liquidity crunch that began in the fall of 1930 and lasted through the spring of 1931. What explains the continued contraction of the banking system thereafter? Answers to this question can be divided into two classes. The first follows the logic of Friedman and Schwartz (1963). The liquidity crisis grew like a snowball rolling down a hill. The initial credit crunch forced some banks out of business. Fear of further failures induced depositors to withdraw additional funds, which forced banks to sell more assets, which drove asset prices even lower, which forced more banks to fail, which confirmed depositors' fears in a continuing cycle of self-fulfilling pessimism. The snowball stopped only when Roosevelt declared a national banking holiday in the winter of 1933 and restored confidence in the safety and soundness of the financial system.

The second follows the logic of Temin (1989). Shocks - droughts, tariff wars, contractionary policies, beggar-thy-neighbor devaluations, declines in autonomous consumption and investment - battered the economy in the early 1930s. England's departure from the gold standard was a particularly severe stimulus. These real shocks reduced asset values and pushed marginal banks into insolvency. The banking crisis came to an end only after economic recovery began in 1933.

The information presented in this article cannot distinguish between those theories. Both are consistent with the data. Both probably explain a portion of the truth. Their relative explanatory power remains one of the key unanswered questions concerning the depression. The former lies at the heart of the monetarist explanation for the Great Depression. The latter lies at the heart of several strands of neo-Keynesian literature.

The patterns presented in this article answer some but far from all questions concerning the causes and consequences of bank failures during the Great Depression. Viewing the data from different perspectives may resolve other riddles. One possibility is comparing the causes of national versus state bank suspensions. A second possibility is comparing the causes of member versus nonmember bank suspensions. Such exercises may help to reconcile the conclusions of Calomiris and Mason (2003), Carlson (2004), and White (1984), who study microdata from member, state, and national banks respectively, with those of Mitchener (2004) and Wicker (1996), who study data on state bank suspensions aggregated at the county, state, and Federal Reserve District levels. Additional insights may be gleaned by comparing urban and rural banks or by examining suspension patterns geographically or weighted by bank size (e.g. assets, liabilities, or capital) or weighted by the length of temporary suspensions (e.g. number of days).

The archival evidence introduced in this article may also illuminate the transmission mechanisms of monetary policy and the linkages between the financial crisis and real economy. Terminal suspensions disrupted financial intermediation and increased the costs of credit intermediation to a greater extent than temporary suspensions. Temporary suspensions were symptoms of liquidity crises and banking panics propelled by sudden swings in depositors' moods. By distinguishing these events, the archival data provides mechanisms for illuminating the 
monetary and non-monetary effects of financial panics and the ways in which Federal Reserve action (or inaction) contributed to the collapse of the economy.

These analyses are topics for future articles. My preliminary explorations along each dimension indicate that none contradict the conclusions justified by the chronological patterns presented in this article. Illiquidity bedeviled banks throughout the depression. Heavy withdrawals played a primary or contributing role in nearly half of all suspensions. Asset problems also bedeviled banks throughout the Great Depression. Slow, doubtful, or worthless assets played a primary or contributing role in over half of all suspensions. The initial banking panic in the fall of 1930 - with its cluster of temporary bank suspensions, bank runs, and collapsing correspondent networks - appears to have been a credit crunch inspired by the collapse of financial conglomerates and propagated by the public's flight from deposits to currency. During later surges in banking crises, the suspension of depository institutions appears to have been driven less by sudden swings in depositors' fears for the safety of banks and more by declines in the values of banks' portfolios.

These conclusions raise new questions concerning the collapse of the banking system during the 1930s. Why did correspondent networks collapse in November and December 1930 but endure even greater shocks during the following three years? Why did some banks which suspended operations reopen for business, while others whose owners and managers also strove to reorganize and reopen, fail to reopen their doors? Why were banks able to avoid suspension by merging with healthy institutions at the last minutes in some states but not in others? Did the policies pursued by state banking departments and Federal Reserve Banks influence the categories and causes of bank changes under duress? Future articles employ the new archival evidence to answer such questions and to advance our efforts to understand the causes and consequences of financial distress during the Great Depression.

\section{REFERENCES}

Board of Governors of the Federal Reserve System. "Memorandum Regarding Preparation of Reports of Changes in Status of Member and Nonmember Banks,” Memo: November 18, 1929. National Archives, Record Group 82, Federal Reserve Central Subject File, 421.113.

Committee on Branch, Group and Chain Banking, "Bank Changes - Definitions of Terms,” Memo: November 5, 1930. National Archives, Record Group 82, Federal Reserve Central Subject File, 421.113-1.

Committee on Branch, Group and Chain Banking. "Comments Regarding Preparation of Form F." 23 November 1931. National Archives, Record Group 82, Federal Reserve Central Subject File, 421.113-1, Forms and Instructions.

---- 1937. "Bank Suspensions in the United States.” Federal Reserve Bulletin. Washington, D.C.: Board of Governors of the Federal Reserve System. September.

Bernanke, B. S., 1983. "Nonmonetary Effects of the Financial Crisis in the Propagation of the Great Depression.” American Economic Review 73, 257-276.

Calomiris, Charles W. and Joseph R. Mason. "Contagion and Bank Failures During The Great Depression: The June 1932 Chicago Banking Panic.” American Economic Review, December 1997, 87(5), pp. 863-883.

"Fundamentals, Panics, and Bank Distress During the Depression.” American Economic Review, December 2003, 93(5): pp. 1615-1646.

Carlson, Mark. “Are Branch Banks Better Survivors? Evidence from the Depression Era.” Economic Inquiry, January 2004, (42), pp. 111-126

Eichengreen, Barry. Golden Fetters. New York: Oxford University Press, 1992.

Friedman, Milton and Schwartz, Anna J. 1963. A Monetary History of the United States, 1867-1960. Princeton: Princeton University Press.

Meltzer, Allan H. "Monetary and Other Explanations for the Start of the Great Depression." Journal of Monetary Economics 2 (1976): 455-72.

Mitchener, Kris James. 2004. Bank Supervision, Regulation, and Instability during the Great Depression. NBER Working Paper 10475. May 2004.

Richardson, Gary, 2006a, "The Records of the Federal Reserve Board of Governors in the National Archives of the United States,” Financial History Review 13(1), 123-134. 
The Australasian Accounting Business \& Finance Journal, February 2007

Richardson: Collapse of United States Banking System Great Depression. Vol. 1, No.1.pp. 39-50.

2006b. "Quarterly Data on the Categories and Causes of Bank Distress during the Great Depression,” NBER Working Paper w12715.

2006c. "Correspondent Clearing and the Banking Panics of the Great Depression,” NBER Working Paper w12716.

2006d. "Bank Distress during the Great Contraction, 1929 to 1933, New Evidence from the Archives of the Board of Governors” NBER Working Paper w12590.

Richardson, Gary and William Troost, 2006. "Monetary Intervention Mitigated Banking Panics During the Great Depression: Quasi-Experimental Evidence from the Federal Reserve District Border in Mississippi, 1929 to 1933.” NBER Working Paper w12591.

Romer, Christina. “The Nation in Depression.” The Journal of Economic Perspectives. Vol 7, No. 2 (Spring, 1993), pp. 19-39.

Temin, Peter. Did Monetary Forces Cause the Great Depression? New York: W.W. Norton, 1976.

--- $\quad$ Lessons from the Great Depression. Cambridge, MA: MIT Press, 1989.

Wheelock, David. "Member Bank Borrowing and the Fed's Contractionary Monetary Policy During the Great Depression.” Journal of Money, Credit and Banking November 1990, (22) pp. 409-426.

White, Eugene. 1984. “A Reinterpretation of the Banking Crisis of 1930.” Journal of Economic History 44 (March): 119-38.

Wicker, Elmus. 1980. “A Reconsideration of the Causes of the Banking Panic of 1930.” Journal of Economic History 40 (September): 571-83.

1996. The Banking Panics of the Great Depression. Cambridge: Cambridge University Press, 1996. 